\title{
Hydroisomerization performance of platinum supported on ZSM-22/ZSM-23 intergrowth zeolite catalyst
}

\author{
Chi Kebin ${ }^{1,2}$, Zhao Zhen ${ }^{1 *}$, Tian Zhijian², Hu Sheng², Yan Lijun², Li \\ Tianshu', Wang Bingchun ${ }^{3}$, Meng Xiangbin², Gao Shanbin², Tan Mingwei ${ }^{2}$ \\ and Liu Yanfeng ${ }^{2}$
}

${ }^{1}$ State Key Laboratory of Heavy Oil Processing, China University of Petroleum, Beijing 102249, China
${ }^{2}$ Petrochemical Research Institute, PetroChina Company Limited, Beijing 100195, China
${ }^{3}$ Dalian Institute of Chemical Physics, Chinese Academy of Sciences, Dalian, Liaoning 116023, China

(C) China University of Petroleum (Beijing) and Springer-Verlag Berlin Heidelberg 2013

\begin{abstract}
Hydroisomerization catalysts Pt/ZSM-22, Pt/ZSM-23, and Pt/ZSM-22/ZSM-23 were prepared by supporting Pt on ZSM-22, ZSM-23, and intergrowth zeolite ZSM-22/ZSM-23, respectively. The typical physicochemical properties of these catalysts were characterized by X-Ray Diffraction (XRD), $\mathrm{N}_{2}$ absorption-desorption, Pyridine-Fourier Transform Infrared (Py-FTIR), Transmission Electron Microscopy (TEM), X-Ray Fluorescence (XRF), Scanning Electron Microscopy (SEM) and $\mathrm{NH}_{3}$ Temperature Programmed Desorption ( $\mathrm{NH}_{3}$-TPD), and the performance of these catalysts in $n$-dodecane hydroisomerization was evaluated in a continuous down-flow fixed bed with a stainless steel tubular reactor. The characterization results indicated that the intergrowth zeolite ZSM-22/ZSM-23 possessed the dual structure of ZSM-22 and ZSM-23, and the catalyst Pt/ZSM-22/ZSM-23 had similar pores and weak acidity to Pt/ZSM-22 and Pt/ZSM-23 catalysts. Moreover, Pt/ZSM-22/ZSM-23 catalyst showed a high selectivity in hydroisomerization of long chain $n$-alkanes to mono-branched isomers. The evaluation results for $n$-dodecane hydroisomerization indicated that the activity of Pt/ZSM-22/ZSM-23 was the lowest, while the hydroisomerization selectivity was the highest among the three catalysts. The maximum yield of $i$-dodecane product was $68.3 \%$ over Pt/ZSM-22/ZSM-23 at $320{ }^{\circ} \mathrm{C}$.
\end{abstract}

Key words: ZSM-22/ZSM-23 intergrowth zeolite, platinum catalyst, $n$-dodecane, hydroisomerization

\section{Introduction}

Environmental regulation is becoming increasingly stringent and the demand for clean gasoline, diesel oil, highquality lubricants and other products is increasing (Kerby et al, 2005). Hydroisomerization became a revolutionary technology in the world's oil refining industry in the twentieth century (Marcilly, 2003), and hydroisomerization can convert $n$-alkanes into isoparaffins with same carbon number, which improves the octane number of gasoline oil (Geng et al, 2004). For diesel oil and lubricating oil production, isoparaffins also can reduce the freezing point or pour point, and improve the viscosity-temperature properties of lubricating oil while maintaining high product yields (Martens et al, 2001; Miller, 1987).

Isomerization catalysts play an important role in the hydroisomerization process. Generally, bifunctional catalysts are used in hydroisomerization of $n$-alkanes. The bifunctions

*Corresponding author. email: zhenzhao@cup.edu.cn

Received August 26, 2012 include hydrogenation-dehydrogenation activity and acidic components (Saberi et al, 2001; Yang et al, 2007; Ramos et al, 2007; Woltz et al, 2006). The metal component of a catalyst is always the hydrogenation-dehydrogenation active component, while zeolite provides the acidic centers for isomerization and cracking reactions. Although regulation of acidity and metal loadings of catalysts can improve the selectivity of isomerization reaction to a certain extent, but it will still lack selectivity and controllability for structure and composition of the products. Introduction of shape-selective molecular sieve into the isomerization catalyst can effectively control the conversion from mono-carbonium ions and di-carbonium ions to tri-carbonium ions, and prohibit tri-carbonium ions from diffusing into the molecular sieve to undertake secondary cracking reactions. Hence the isomerization selectivity is enhanced.

Silicoaluminophosphate molecular sieves, such as SAPO11, with tubular 10-membered ring channels with elliptical pore openings, are widely used as support with acid sites and shape-selective pore openings. However, some other zeolites, such as ZSM-22 and ZSM-23, are also good choices for their 
unique characteristics. ZSM-22 (with TON (edingtonite) topology structure) and ZSM-23 (with MTT (omega structure ) topology structure) have almost the same slightly elliptical pore openings of $0.44 \times 0.55 \mathrm{~nm}$ and $0.45 \times 0.52 \mathrm{~nm}$, respectively. Their pore channel size is similar to the kinetic diameter of normal alkanes and smaller than that of branched alkanes. Use of these zeolites in hydroisomerization catalyst can transform long chain alkanes into isomeric products with high yields (Wittenbrink et al, 2003; Aldrich and Wittenbrink, 1999; Miller and Rosenbaum, 2005; Murphy et al, 2010). Compared with SAPO-11, ZSM-22 and ZSM-23 zeolites exhibit much higher activity, but low selectivity for hydroisomerization of long chain alkanes (Hu et al, 2005).

The development of novel zeolites as suitable supports for hydroisomerization catalysts has developed from simple mechanical mixtures of two or more molecular sieves to intergrowth zeolites (Zones et al, 2004). According to crystallography, only zeolites with the same initial structure, and growing with strict and orderly arrangement, will form intergrowth zeolites. Niu et al (2005) and Francesconi et al (2005) synthesized co-crystallization zeolites MCM-22/ ZSM-35 and MFI/MEL, respectively, and their catalytic properties were different from those of the individual zeolites. Rollmann et al (1999) and Zones et al (2004) have synthesized ZSM-22/ZSM-23 co-crystallization zeolites, which were different in lattice parameters, pore structure, and surface acidity from their parent zeolites. Little has been reported about the hydroisomerization performance of $n$-dodecane over ZSM-22/ZSM-23 intergrowth zeolites. In this work, hydroisomerization catalysts Pt/ZSM-22, Pt/ZSM23 and Pt/ZSM-22/ZSM-23 were prepared by loading Pt on ZSM-22, ZSM-23, and intergrowth zeolite ZSM-22/ZSM23 , respectively. The physicochemical properties of these catalysts were characterized by using X-Ray Diffraction (XRD), X-Ray Fluorescence (XRF), Transmission Electron Microscopy (TEM), Scanning Electron Microscopy (SEM), Brunauer-Emmett-Teller (BET) surface area measurement, Pyridine-Fourier Transform Infrared (Py-FTIR), and $\mathrm{NH}_{3}-$ Temperature Programmed Desorption $\left(\mathrm{NH}_{3}-\mathrm{TPD}\right)$ techniques. The hydroisomerization performances of $n$-dodecane on these catalysts were studied.

\section{Experimental}

\subsection{Catalyst preparation}

ZSM-22 and ZSM-23 were prepared by the hydrothermal method described by Kokotailo et al (1985) and Rohrman et al (1985); ZSM-22/ZSM-23 intergrowth zeolite was synthesized as described by Wang et al (2009). Three catalysts, Pt/ZSM22, Pt/ZSM-23, and Pt/ZSM-22/ZSM-23, were prepared with the same metal loading using ZSM-22, ZSM-23 and ZSM-22/ ZSM-23 separately and gamma-alumina $\left(\mathrm{Al}_{2} \mathrm{O}_{3}\right)$ as carrier. Then the extrudates were dried at $110^{\circ} \mathrm{C}$ for $24 \mathrm{~h}$ and calcined at $550^{\circ} \mathrm{C}$ for $4 \mathrm{~h}$. The catalyst supports obtained by the above procedures were impregnated with $\mathrm{H}_{2} \mathrm{PtCl}_{6}$ solution by the vacuum impregnation method. The Pt/ZSM-22, Pt/ZSM23 and Pt/ZSM-22/ZSM-23 catalysts were dried and finally calcined at $550{ }^{\circ} \mathrm{C}$ for $4 \mathrm{~h}$. The $\mathrm{SiO}_{2}$ and $\mathrm{Al}_{2} \mathrm{O}_{3}$ contents in the molecular sieves were determined by X-ray fluorescence spectrometry (Philips Magix601, Netherlands). The $\mathrm{SiO}_{2}$ contents of ZSM-22, ZSM-23 and ZSM-22/ZSM-23 were $97.4 \mathrm{wt} \%, 97.4 \mathrm{wt} \%, 97.3 \mathrm{wt} \%$, respectively. The contents of $\mathrm{Al}_{2} \mathrm{O}_{3}$ for these three samples were $1.96 \mathrm{wt} \%, 1.97 \mathrm{wt} \%$, $1.95 \mathrm{wt} \%$, respectively. The Si/Al molar ratios of the three molecular sieves were very close.

\subsection{Catalyst Characterization}

XRD patterns of the catalysts were recorded with a Rigaku D/max-r B X-ray diffractometer (Rigaku, Japan) at 40 $\mathrm{kV}$ and $50 \mathrm{~mA}$, using $\mathrm{Cu} \mathrm{K} \alpha$ radiation $(\lambda=1.5418 \AA)$, with a scanning angle of $2^{\circ}-70^{\circ}$, and a scan rate of $2 \% \mathrm{~min}$.

The TEM images of the catalysts were obtained by using a JEOL JEM 2100 electron microscope equipped with a field emission source at an accelerating voltage of $200 \mathrm{kV}$ (JEOL, Japan). The average particle diameter was calculated from the mean diameter frequency distribution. The crystallite sizes and morphology of the catalysts were determined by the scanning electron microscopy using a JSM6360LA scanning electron microscope (JEOL, Japan) at a voltage of $20 \mathrm{kV}$.

Nitrogen adsorption/desorption measurements were performed on an ASAP2405M Micromeritics surface area and pore analyzer (Micromeritics, USA). Then the calcined catalyst was calcined at $550{ }^{\circ} \mathrm{C}$ for $4 \mathrm{~h}$. The catalyst powder sample $(30-40 \mathrm{mg})$ was degassed at a sample preparation station at $300{ }^{\circ} \mathrm{C}$ and $1.33 \times 10^{-3} \mathrm{~Pa}$ for $15 \mathrm{~h}$. It was then transferred to the analysis station for adsorption and desorption at $-196^{\circ} \mathrm{C}$ in liquid nitrogen. The catalyst surface area was calculated using the multipoint BET equation for the linear region in the $\mathrm{P} / \mathrm{P}_{0}$ range of $0.05-0.35$ (Gregg and Sing, 1982). The catalyst pore volume was calculated on the basis of the maximum amount of nitrogen adsorbed at $\mathrm{P} / \mathrm{P}_{0}=0.99$.

$\mathrm{NH}_{3}$-TPD measurements were performed on an Auto Sorb-I-C physical chemistry adsorption instrument (Quantachrome, USA). The catalyst sample ( $0.2 \mathrm{~g})$ was put in a quartz tube and heated to $347^{\circ} \mathrm{C}$, in a helium flow of $40 \mathrm{~mL} /$ $\mathrm{min}$ for $2 \mathrm{~h}$ to remove any adsorbed water, and then cooled to room temperature. Then it was saturated with ammonia until equilibrium was reached. Helium was then introduced into the tube to purge the sample for $0.5 \mathrm{~h}$. After the baseline was stable, the sample was heated to $600^{\circ} \mathrm{C}$ at a rate of $10^{\circ} \mathrm{C} / \mathrm{min}$. The desorbed ammonia was detected by thermal conductivity detector (TCD).

FT-IR spectra of adsorbed pyridine were recorded on a Nicolet Magna 550 Fourier transform infrared spectrometer (Nicolet, USA), using a self-supporting wafer in an in-situ cell. The wafer was made of $10 \mathrm{mg}$ catalyst sample and pretreated at $500^{\circ} \mathrm{C}$ for $5 \mathrm{~h}$ in a vacuum of $1.33 \times 10^{-2} \mathrm{~Pa}$, and then cooled to room temperature, followed by pyridine adsorption. Adsorbed pyridine was removed by degassing for 20 minutes at room temperature, $200^{\circ} \mathrm{C}$ or $350^{\circ} \mathrm{C}$, in vacuum. Then FT-IR spectra of the adsorbed pyridine were recorded. The two bands observed at $1,450 \mathrm{~cm}^{-1}$ and $1,540 \mathrm{~cm}^{-1}$ could be assigned to pyridine adsorbed on Lewis and Brönsted acid sites, respectively (Nieminen et al, 2004). The calculation of acid amount is based on the Lambert-Beer equation as described in details in literature (Emies, 1993). 


\subsection{Catalytic activity evaluation}

The reaction of $n$-dodecane hydroisomerization was carried out in a continuous fixed-bed flow reactor (as shown in Fig. 1) with an internal diameter of $12 \mathrm{~mm}$. The catalyst sample was crushed to 20-40 mesh, and then the sample was loaded into the isothermal zone of the reactor. The remaining part of the reactor was filled with inert alumina. The catalyst was reduced in situ before the evaluation test at $450^{\circ} \mathrm{C}$ for $4 \mathrm{~h}$ under a $\mathrm{H}_{2}$ flow of $30 \mathrm{~mL} / \mathrm{min}$ at $1.0 \mathrm{MPa}$.
After the reduction of the catalyst, the reactor was adjusted to the desired reaction temperature, and then the $n$-dodecane was injected into the reactor. Experimental conditions were as follows: catalyst weight of $7.0 \mathrm{~g}$; reaction temperatures of $250-350^{\circ} \mathrm{C}$; hydrogen pressure of $8.0 \mathrm{MPa}$; LHSV of 1.0 $\mathrm{h}^{-1} ; \mathrm{H}_{2} / n-\mathrm{C}_{12}$ volume ratio of 500:1. Sampling was performed every $6 \mathrm{~h}$ in stream, and the products were analyzed by gas chromatography (Agilent 6890) with a capillary HP-1 column $(0.2 \mathrm{~mm}$ I.D. $\times 50 \mathrm{~m})$ and FID detector.

\section{Condenser Back pressure valve}

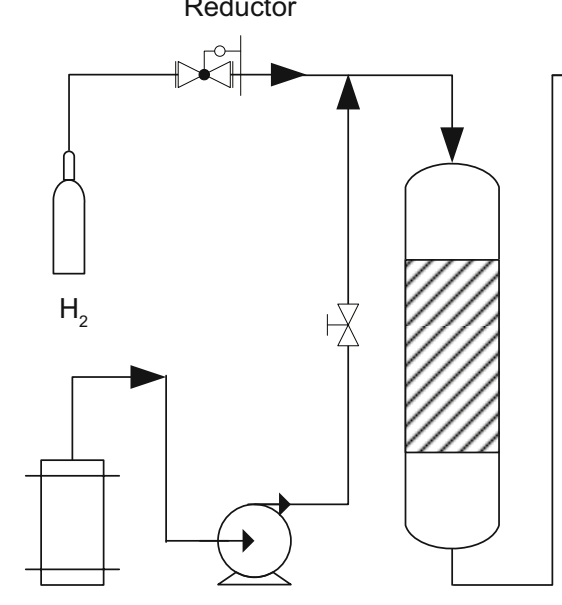

Feedstock Pump Reactor

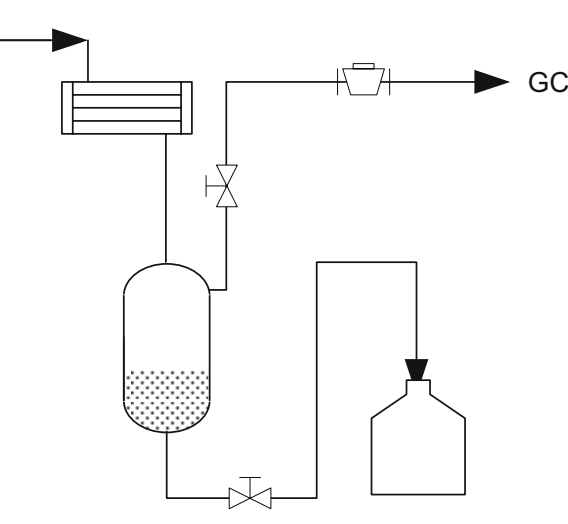

Separator Product receiver

Fig. 1 Flow scheme for the hydroisomerization process with a $10 \mathrm{~mL}$ fixed bed reactor

Conversion $(X)$, isomerization selectivity $\left(S_{\mathrm{i}}\right)$, and yields $(Y)$ are defined as follows:

$$
\begin{aligned}
& X(\%)=\frac{(n \text {-dodecane })_{\text {feed }}-(n \text {-dodecane })_{\text {product }}}{(n \text {-dodecane })_{\text {feed }}} \times 100 \\
& S_{i}(\%)=\frac{(i \text {-dodecane })_{\text {product }}}{(i \text {-dodecane })_{\text {product }}+(\text { cracking products })_{\text {product }}} \times 100 \\
& Y_{\mathrm{i}}(\%)=\frac{(i \text {-dodecane })_{\text {product }}}{(n \text {-dodecane })_{\text {feed }}} \times 100 \\
& Y_{\mathrm{c}}(\%)=\frac{(\text { cracking products })_{\text {product }}}{(n \text {-dodecane })_{\text {feed }}} \times 100 \\
& Y_{\text {Mu }}(\%)=\frac{(\text { multibranched isomers })_{\text {product }}}{(n \text {-dodecane })_{\text {feed }}} \times 100 \\
& Y_{\text {Mo }}(\%)=\frac{(\text { monobranched isomers })_{\text {product }}}{(n \text {-dodecane })_{\text {feed }}} \times 100
\end{aligned}
$$

where,

( $n$-dodecane $)_{\text {feed }}$ - the mass concentration of dodecane in the feedstock;

( $n$-dodecane $)_{\text {product }}-$ the mass concentration of dodecane in the product;
( $i$-dodecane $)_{\text {product }}$ - the mass concentration of isododecane in the product;

(cracking products) $)_{\text {product }}$ - the mass concentration of cracking products in the product;

(multibranched isomers) $_{\text {product }}-$ the mass concentration of multibranched isomers in the product;

(monobranched isomers) $)_{\text {product }}-$ the mass concentration of monobranched isomers in the product.

\section{Results and discussion}

\subsection{Physicochemical properties of catalysts}

The XRD pattern of Pt/ZSM-22/ZSM-23 (as shown in Fig. 2) was clearly different from those of Pt/ZSM-22 and Pt/ ZSM-23. The positions of the diffraction peaks of Pt/ZSM22 were at $8.15^{\circ}, 10.16^{\circ}, 12.77^{\circ}, 20.36^{\circ}, 24.25^{\circ}, 24.62^{\circ}$ and $25.71^{\circ}$. The positions of the diffraction peaks of Pt/ZSM-23 were at $8.22^{\circ}, 11.42^{\circ}, 19.82^{\circ}, 21.07^{\circ}, 23.05^{\circ}, 23.99^{\circ}, 24.23^{\circ}$ and $24.82^{\circ}$. It can be seen that ZSM-22/ZSM-23 intergrowth zeolite was a novel material, which had a dual structure of both ZSM-22 and ZSM-23. In our previous work (Wang, 2009), it was found that ZSM-22/ZSM-23 intergrowth zeolite was composed of about $60 \mathrm{wt} \%$ of ZSM-23 and $40 \mathrm{wt} \%$ of ZSM-22 zeolites. No characteristic diffraction peaks belong to metallic Pt were observed in the wide angle region $\left(39^{\circ}\right.$, $46^{\circ}, 67^{\circ}$ and $81^{\circ}$ ) of XRD patterns of Pt/ZSM-23 and Pt/ZSM22/ZSM-23. These results may indicate that Pt particles are very small and well dispersed on the catalyst (Mazurek et al, 2006). 


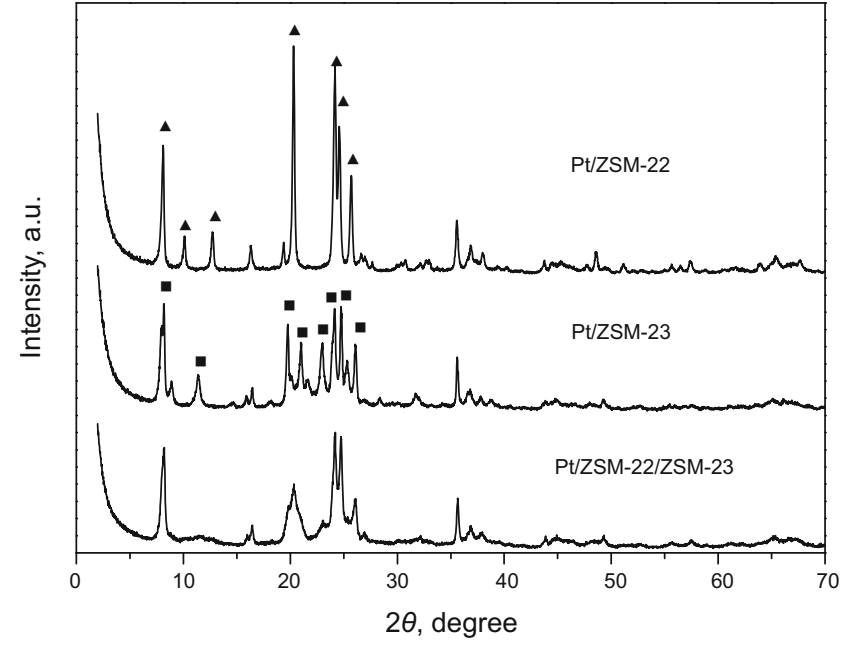

Fig. 2 XRD patterns of Pt/ZSM-22, Pt/ZSM-23 and Pt/ZSM-22/ZSM-23

Notes: $\boldsymbol{\Delta}$ - characteristic peak of ZSM-22; - characteristic peak of ZSM-23

Fig. 3 shows the TEM images and size distribution of $\mathrm{Pt}$ nanoparticles on the catalysts of Pt/ZSM-23 and Pt/ZSM22/ZSM-23. The spherical Pt nanoparticles on the surface of both the catalysts can be clearly observed in TEM images (shown in the white circle). Pt nanoparticles on both ZSM23 and ZSM-22/ZSM-23 were highly dispersed and uniform in size. The mean diameters of Pt nanoparticles for all the catalysts were about $2.0 \mathrm{~nm}$. The TEM results are consistent with XRD analysis, indicating that the Pt nanoparticles are well dispersed and very small in size.

The SEM images of Pt/ZSM-22, Pt/ZSM-23 and Pt/ ZSM-22/ZSM-23 (as shown in Fig. 4) showed that the three catalysts all had well-defined morphology, and the size of the particles was uniform. The Pt/ZSM-22 had spindle-shaped conglomerates with 3-4 $\mu$ m rod-like crystals, Pt/ZSM-23 had nest-shaped conglomerates with $2 \mu \mathrm{m}$ acicular crystals, and Pt/ZSM-22/ZSM-23 was composed of needle-shaped crystals with uniform particle size. The needle-shaped crystals clustered together and formed spherical aggregates which were larger than $10 \mu \mathrm{m}$, indicating that Pt/ZSM-22/ZSM-23 was a catalyst with a new type of zeolite which was different from Pt/ZSM-22 and Pt/ZSM-23.

These data given in Table 1 showed that Pt/ZSM-22, Pt/ZSM-23 and Pt/ZSM-22/ZSM-23 had similar physical properties. The $\mathrm{N}_{2}$ adsorption-desorption isotherm curves in Fig. 5 showed that all the synthesized samples had well-

Table 1 Physicochemical properties of catalysts

\begin{tabular}{cccc}
\hline Properties & Pt/ZSM-22 & Pt/ZSM-23 & Pt/ZSM-22/ZSM-23 \\
Shape & Trifoliate & Trifoliate & Trifoliate \\
Metal content, $\mathrm{wt} \%$ & 0.5 & 0.5 & 0.5 \\
Specific surface area, $\mathrm{m}^{2} \cdot \mathrm{g}^{-1}$ & 181 & 185 & 183 \\
Pore volume, $\mathrm{mL} \cdot \mathrm{g}^{-1}$ & 0.28 & 0.26 & 0.28 \\
Average pore $\mathrm{size}, \mathrm{nm}^{-1}$ & 0.89 & 0.91 & 0.75 \\
Crushing strength, $\mathrm{N} \cdot \mathrm{cm}^{-1}$ & 122 & 122 & 123 \\
\hline
\end{tabular}
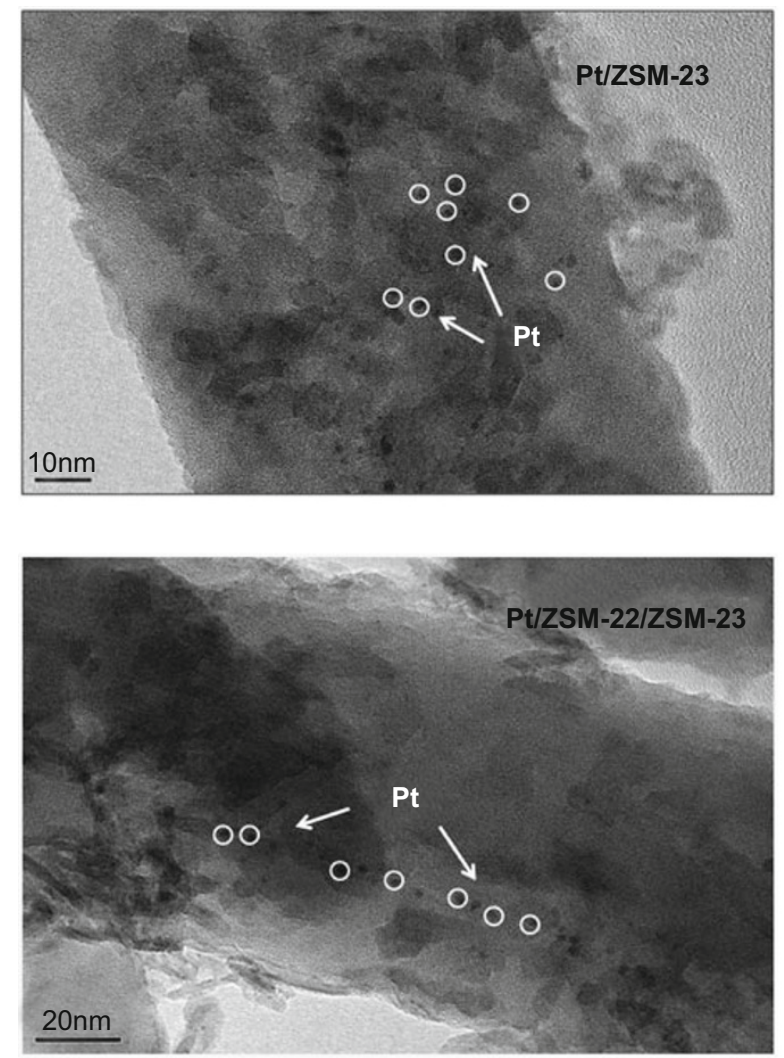

Fig. 3 TEM images of Pt/ZSM-23 and Pt/ZSM-22/ZSM-23

defined adsorption-desorption hysteresis loops (Coasne et al, 2002) indicating the existence of mesoporous materials, namely the secondary pores.

In the hydroisomerization of long chain $n$-alkanes, the acidity of catalyst plays a major role in the catalytic performance and determines the product distribution. $\mathrm{NH}_{3}$ TPD and FTIR spectra of adsorbed pyridine were used to measure the number, the acid type and strength of acid sites of Pt/ZSM-22, Pt/ZSM-23 and Pt/ZSM-22/ZSM-23 samples.

Fig. 6 shows the $\mathrm{NH}_{3}$-TPD curves of Pt/ZSM-22, Pt/ZSM23 , and Pt/ZSM-22/ZSM-23. The desorption peak at around $200-240{ }^{\circ} \mathrm{C}$ is attributed to weak acid sites, the desorption peak at around $290-300{ }^{\circ} \mathrm{C}$ is attributed to medium acid sites and the desorption peak at around $400-430{ }^{\circ} \mathrm{C}$ is attributed to strong acid sites. Assuming the stoichiometry of one $\mathrm{NH}_{3}$ molecule per acid site, the total number and the distribution of acid sites can be obtained from the Gaussian deconvolution of TPD curves. The areas of $\mathrm{NH}_{3}$-TPD desorption peaks for catalysts with different supports are listed in Table 2. In Fig. 6, it can be seen that the area of the low temperature peak is much larger than that of the high temperature peak, indicating that Pt/ZSM-22, Pt/ZSM-23 and Pt/ZSM-22/ZSM23 possess more weak acidity sites. Comparing the data in Table 2, the number of strong acid sites for Pt/ZSM-23 was higher than those of other two samples which had similar strong acid sites. The number of weak acid sites and medium acid sites for Pt/ZSM-22 was higher than that of Pt/ZSM-22/ ZSM-23. The total acid amount order of the three catalysts was Pt/ZSM-22/ZSM-23 < Pt/ZSM-22 < Pt/ZSM-23. Lower acidity favors the isomerization reaction and avoids excessive secondary cracking, while stronger acidity is favorable for 

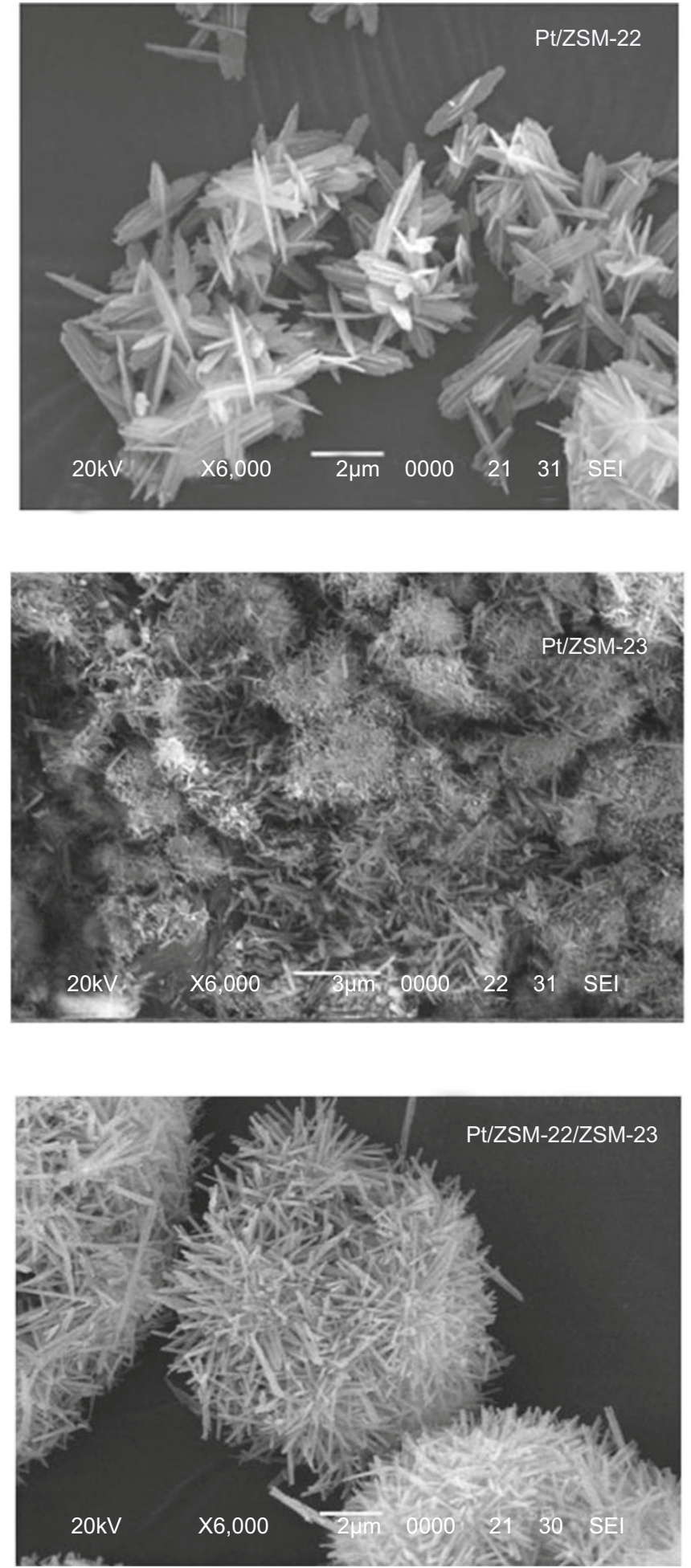

Fig. 4 SEM images of Pt/ZSM-22, Pt/ZSM-23 and Pt/ZSM-22/ZSM-23

cracking reaction (Kwang and Son, 2000; Thybaut et al, 2005). Hence, Pt/ZSM-22/ZSM-23 had lower reactivity and higher hydroisomerization selectivity than Pt/ZSM-22 or Pt/ ZSM-23.

The acidity values of the Brönsted and Lewis acid sites of the catalysts can be calculated from the peak areas of the FT-IR spectra obtained by pyridine adsorption. The Brönsted and Lewis acidity of Pt/ZSM-22, Pt/ZSM-23, and Pt/ZSM22/ZSM-23 catalysts at $200^{\circ} \mathrm{C}$ and $350^{\circ} \mathrm{C}$ are listed in Table

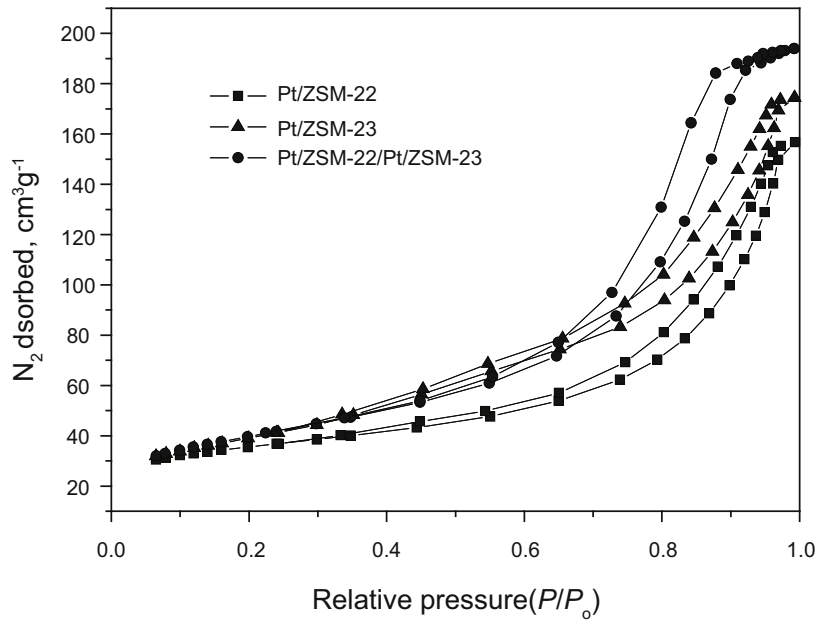

Fig. $5 \mathrm{~N}_{2}$ adsorption-desorption isotherms of Pt/ZSM-22/ZSM-23

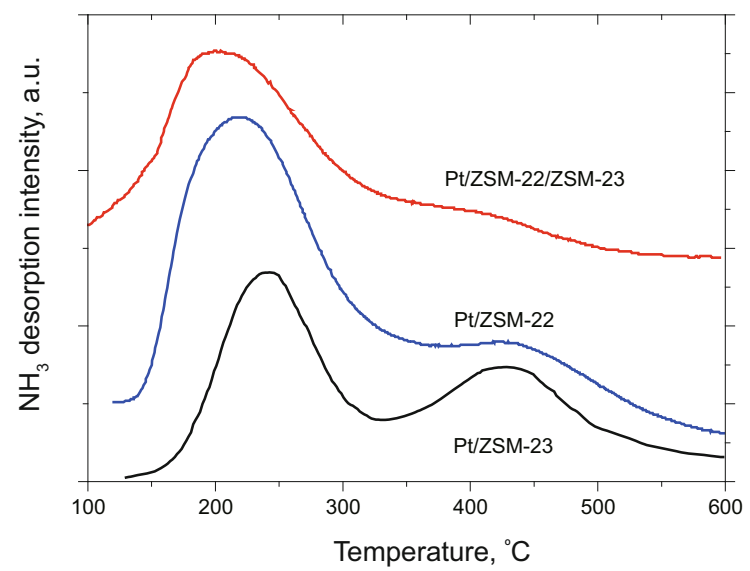

Fig. $6 \mathrm{NH}_{3}$-TPD profiles of Pt/ZSM-22, Pt/ZSM-23 and Pt/ZSM-22/ZSM-23

3. Generally, pyridine adsorbed on the weak acid sites was desorbed at a relatively low temperature of $200^{\circ} \mathrm{C}$, and pyridine which was adsorbed on strong acid sites desorbed at a relatively high temperature of $350^{\circ} \mathrm{C}$. The acidity values of Brönsted and Lewis acid sites decreased significantly after the three catalysts were degassed from $200^{\circ} \mathrm{C}$ to $350^{\circ} \mathrm{C}$. This clearly indicated that the weak acid sites exist in Pt/ZSM22, Pt/ZSM-23, and Pt/ZSM-22/ZSM-23. The data in Table 3 also showed that the number of Brönsted acid sites decreased in the order: Pt/ZSM-23 > Pt/ZSM-22 > Pt/ZSM-22/ZSM-23. The total acidity (Brönsted + Lewis) followed the same order as that of Brönsted acid sites. This result clearly indicated that ZSM-22/ZSM-23 intergrowth zeolite exhibited a lower number of acid sites than ZSM-22 or ZSM-23 zeolite, in good agreement with the results obtained from $\mathrm{NH}_{3}$-TPD.

\subsection{Evaluation results of $n$-dodecane hydroisomerization over Pt-zeolite catalysts}

Hydroisomerization reactions generally take place on bifunctional catalysts containing metallic sites for hydrogenation/dehydrogenation and acid sites for skeletal isomerization via carbenium ions (Martens et al, 1989; Weitkamp, 1982; Liu et al, 2004; Alvarez et al, 1996; Campelo et al, 1998; Girgis and Tsao, 1996; Walendziewski 
Table 2 The $\mathrm{NH}_{3}$-TPD Data of Pt/ZSM-22, Pt/ZSM-23, and Pt/ZSM-22/ZSM-23

\begin{tabular}{ccccc}
\hline Sample & Weak acidity & Medium acidity & Strong acidity & Total acidity \\
\hline Pt/ZSM-22 & $1.12 \mathrm{E}-9$ & $3.86 \mathrm{E}-10$ & $2.53 \mathrm{E}-10$ & $1.76 \mathrm{E}-9$ \\
Pt/ZSM-23 & $8.34 \mathrm{E}-10$ & $1.74 \mathrm{E}-10$ & $8.24 \mathrm{E}-10$ & $1.83 \mathrm{E}-9$ \\
Pt/ZSM-22/ZSM-23 & $9.91 \mathrm{E}-10$ & $3.12 \mathrm{E}-10$ & $2.27 \mathrm{E}-10$ & $1.53 \mathrm{E}-9$ \\
\hline
\end{tabular}

Table 3 Brönsted and Lewis acidity of Pt/ZSM-22, Pt/ZSM-23, and Pt/ZSM-22/ZSM-23 catalysts

\begin{tabular}{ccccccccc}
\hline \multirow{2}{*}{ Sample } & \multicolumn{3}{c}{$200^{\circ} \mathrm{C}$} & & \multicolumn{3}{c}{$350^{\circ} \mathrm{C}$} \\
\cline { 2 - 3 } \cline { 7 - 8 } & $\begin{array}{c}\text { B acid } \\
\mathrm{mmol} / \mathrm{g}\end{array}$ & $\begin{array}{c}\mathrm{L} \text { acid } \\
\mathrm{mmol} / \mathrm{g}\end{array}$ & $\begin{array}{c}\text { Total acid } \\
\mathrm{mmol} / \mathrm{g}\end{array}$ & & $\begin{array}{c}\text { B acid } \\
\mathrm{mmol} / \mathrm{g}\end{array}$ & $\begin{array}{c}\mathrm{L} \text { acid } \\
\mathrm{mmol} / \mathrm{g}\end{array}$ & $\begin{array}{c}\text { Total acid } \\
\mathrm{mmol} / \mathrm{g}\end{array}$ \\
\hline Pt/ZSM-22 & 0.119 & 0.118 & 0.237 & & 0.115 & 0.026 & 0.141 \\
Pt/ZSM-23 & 0.236 & 0.109 & 0.345 & & 0.218 & 0.046 & 0.264 \\
Pt/ZSM-22/ZSM-23 & 0.096 & 0.123 & 0.219 & & 0.076 & 0.051 & 0.127 \\
\hline
\end{tabular}

and Pniak, 2003).

According to the classical isomerization mechanism (Mills et al, 1953), paraffins were dehydrogenated on the metal active sites to produce olefins, which were subsequently protonated on the Brönsted acid sites to form the corresponding alkylcarbenium ions. These carbenium ions undergo skeletal rearrangement and $\beta$-scission, followed by deprotonation and hydrogenation processes over the metal sites to form iso-paraffins (Park and Ihm, 2000).

The acidity of the catalyst plays a major role in the hydroisomerization and hydrocracking reactions. Both the density and strength distribution of acid sites are important for the activity and selectivity of these catalysts, and should be kept in proper balance between acidity and acid distribution. Catalysts with a high hydrogenation activity and a weak acidity were usually more favorable for hydroisomerization
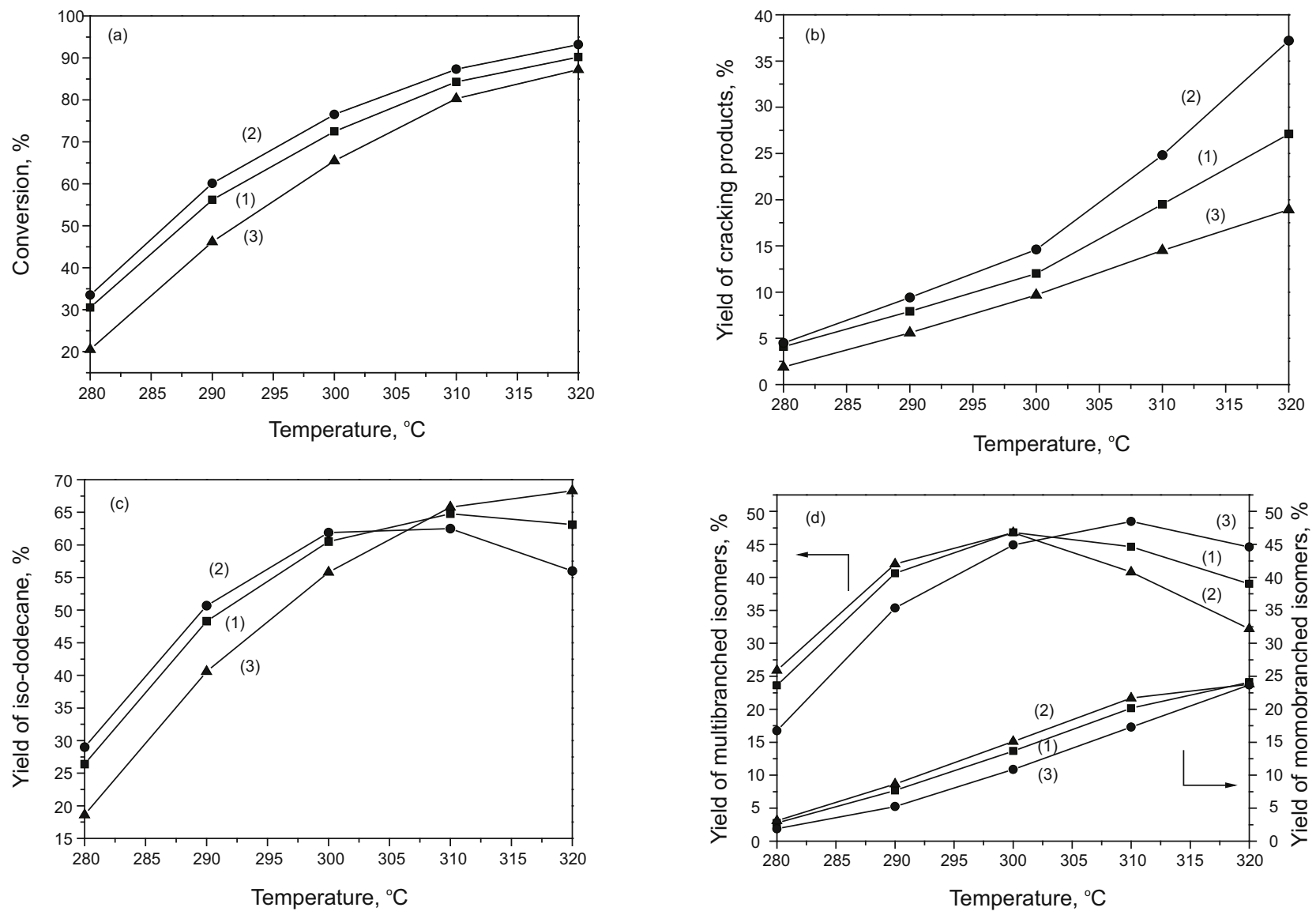

Fig. 7 Influence of reaction temperature $(T)$ on the conversion $(X)$, yield of cracking products $\left(Y_{\mathrm{c}}\right)$, yield of iso-dodecane $\left(Y_{\mathrm{i}}\right)$, and yield of multibranched isomers $\left(Y_{\mathrm{Mu}}\right)$ and monobranched isomers $\left(Y_{\mathrm{Mo}}\right)$ over the Pt catalysts.

Notes: (1) Pt/ZSM-22; (2) Pt/ZSM-23; (3) Pt/ZSM-22/ZSM-23 
than for hydrocracking.

Fig. 7 shows the $n$-dodecane conversion, yield of cracking products, $i$-dodecane, mono-branched and multibranched isomers at different reaction temperatures over a series of catalysts prepared with different zeolites. In Fig. 7 (a), the activity of the three catalysts for hydroisomerization of $n$-dodecane follows the order: Pt/ZSM-23>Pt/ZSM$22>\mathrm{Pt} / \mathrm{ZSM}-22 / \mathrm{ZSM}-23$, since the isomerization activity of $n$-alkanes mainly relies on the amounts of strong acid-sites (Höchtl et al, 1999). With increasing reaction temperature, the conversion of $n$-dodecane, yield of cracking products and multi-branched isomers increased gradually, the yield of $i$-dodecane and mono-branched isomers firstly increased and then decreased; when the reaction temperature was greater than $310^{\circ} \mathrm{C}$, the yield of $i$-dodecane decreased as follows: $\mathrm{Pt} /$ ZSM-22/ZSM-23>Pt/ZSM-22>Pt/ZSM-23, and the yield of $i$-dodecane reached a maximum value of $68.3 \%$ for $\mathrm{Pt} / \mathrm{ZSM}$ 22/ZSM-23 at $320^{\circ} \mathrm{C}$. Because the acidity of Pt/ZSM-22/ ZSM-23 was weaker than that of Pt/ZSM-22 or Pt/ZSM-23, the Pt/ZSM-22/ZSM-23 catalyst could reduce the occurrence of further cracking reactions, and hence the selectivity of the isomerization reaction increased, and excessive cracking reactions were avoided (Gopal and Smirniotis, 2004). At high temperature $\left(T>310^{\circ} \mathrm{C}\right)$, for Pt/ZSM-22 and Pt/ZSM23 , high conversions were obtained due to the hydrocracking reaction (Fig. 7 (b)), since the main reactions changed from hydroisomerization to hydrocracking at high temperatures. At low temperatures $\left(T<310^{\circ} \mathrm{C}\right)$, the hydroisomerization of $n$-dodecane was the main reaction on Pt/ZSM-22, Pt/ZSM-23, and Pt/ZSM-22/ZSM-23 (Fig. 7 (b)). $Y_{\mathrm{Mu}} / Y_{\mathrm{Mo}}$ increased (Fig. 7 (d)), indicating that low temperature was favorable to the formation of mono-branched isomers, but high temperature was favorable to the formation of multi-branched isomers.

The curves of cracking product yield, mono-branched and multi-branched isomer yields as a function of $n$-dodecane conversion are shown in Fig. 8. The main products of $n$-dodecane hydroisomerization were mono-branched isomers on Pt/ZSM-22, Pt/ZSM-23, and Pt/ZSM-22/ZSM-23. When the $n$-dodecane conversion was above $80 \%$, the proportion of multi-branched products increased significantly. This was because the acidity of Pt/ZSM-22/ZSM-23 was weak, and the multi-branched isomers were the secondary products of isomerization from mono-branched isomers. At low conversion, the amount of mono-branched isomers was less than $n$-alkanes, and competitive adsorption on the catalyst surface favors $n$-alkanes, therefore mono-branched products were first converted from $n$-alkanes. With the increase of $n$-dodecane conversion, the concentration of mono-branched products increased and then further reactions from monobranched products to multi-branched products took place, as a result, the amount of multi-branched products increased. As the conversion of $n$-dodecane was above $80 \%$, the total amount of mono-branched products was more than that of $n$-alkanes, so the reaction rate from mono-branched products to multi-branched products increased rapidly, and the proportion of multi-branched products increased. The reason is that the acidity of $\mathrm{Pt} / \mathrm{ZSM}-23$ was stronger than those of $\mathrm{Pt} /$ ZSM-22 and Pt/ZSM-22/ZSM-23 catalysts, so the products
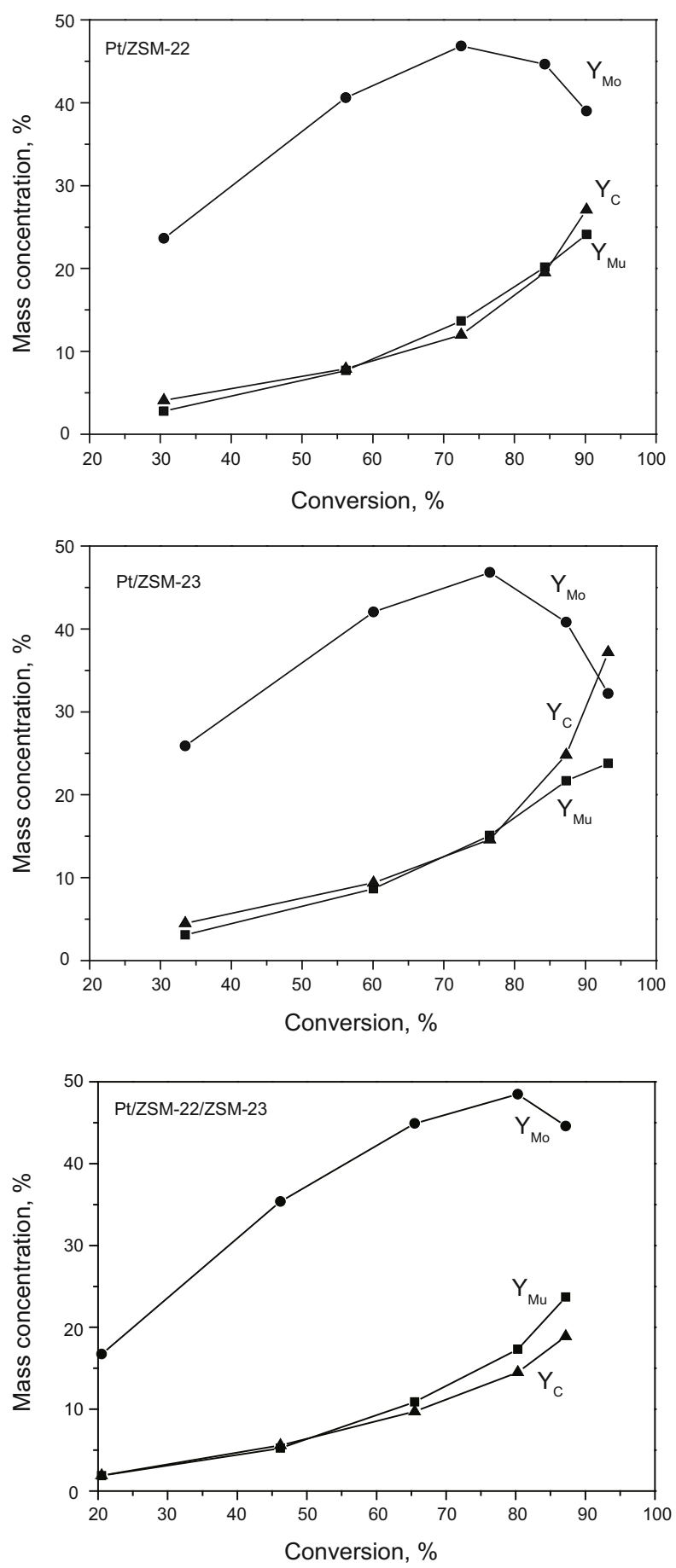

Fig. 8 Influence of $n$-dodecane conversion $(X)$ on yield of cracking products $\left(Y_{\mathrm{C}}\right)$, yield of multibranched isomers $\left(Y_{\mathrm{Mu}}\right)$, and yield of monobranched isomers $\left(Y_{\mathrm{Mo}}\right)$ over the Pt-zeolite catalysts

over Pt/ZSM-23 were mainly from hydrocracking reactions, and the typical products with low molecular weights and high saturation states were produced.

The carbon number distribution of cracking products on Pt-containing catalysts with different zeolite carriers (Fig. 9) indicates that the concentrations of $\mathrm{C}_{1}, \mathrm{C}_{2}$ and $\mathrm{C}_{10}$ in cracking products are very low, which shows that the isomerization and cracking reactions take place on the acid centers, rather than following the hydrogenolysis mechanism on the metal center. For Pt/ZSM-22 and Pt/ZSM-23, small molecules such 


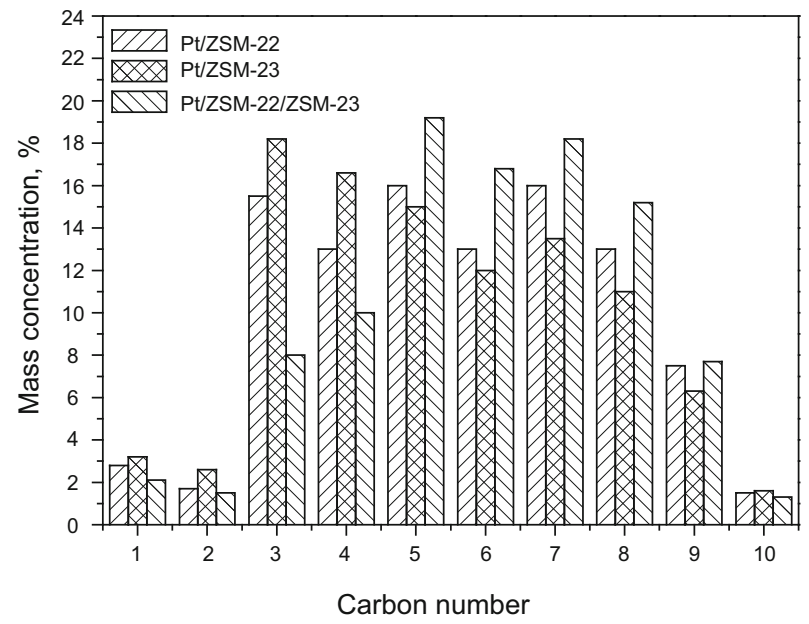

Fig. 9 Carbon number distribution in cracking products of $n$-dodecane over different catalysts

as $\mathrm{C}_{3}$ and $\mathrm{C}_{4}$ are high in cracking products, indicating the existence of secondary cracking reactions, which is relevant to the stronger acidity of catalysts. For Pt/ZSM-22/ZSM23 , the products from $\mathrm{C}_{5}$ to $\mathrm{C}_{8}$ are in high concentrations in cracking products, which is related to the weaker acidity of $\mathrm{Pt} / \mathrm{ZSM}-22 / \mathrm{ZSM}-23$, thus severe secondary cracking reaction are avoided. Pt/ZSM-22, Pt/ZSM-23 and Pt/ZSM-22/ZSM23 are all 10-membered ring zeolites, and have an elliptical tubular pore structure, which can limit the generation of multi-branched isomers, especially those isomers with more than three-branches. The isomerization products are mainly mono-branched isomers, and the position of branched-chain is at the end of the main skeleton chain.

\section{Conclusions}

Intergrowth zeolite ZSM-22/ZSM-23 is a novel catalytic material with a dual structure of ZSM-22 and ZSM-23. It has similar pores and weaker acidity compared with $\mathrm{Pt} /$ ZSM-22 or Pt/ZSM-23 catalysts, and it exhibited a higher hydroisomerization selectivity for long chain $n$-alkanes. The typical product distribution was mainly mono-branched isomers. Although the reactivity of Pt/ZSM-22/ZSM-23 was the lowest, the hydroisomerization selectivity was the highest among the three catalysts, the $i$-dodecane yield reached $68.3 \%$ over $\mathrm{Pt} / \mathrm{ZSM}-22 / \mathrm{ZSM}-23$ at $320^{\circ} \mathrm{C}$.

The selectivity of hydrocarbons' skeletal isomerization rearrangement depends on the acidity and the amount of acid sites of the catalyst, and the controlling of appropriate shapeselectivity, and the balance of weak and moderate acidity are beneficial to catalyzing hydroisomerization, while strong acidity facilitates hydrocracking reactions. Suitable pore structure limits the generation of multi-branched isomers, so inhibiting cracking reactions.

\section{Acknowledgement}

The authors acknowledge the financial supports form Petrochina (050508-04-02) and the National Natural Science Foundation of China (No.21073235, and 20833011).

\section{References}

Aldrich H S and Wittenbrink R J. Lubricant base oil having improved oxidative stability. US Patent, 6008164. 1999

Alvarez F, Ribeiro F R, Perot G, et al. Hydroisomerization and hydrocracking of alkanes: 7. Influence of the balance between acid and hydrogenating functions on the transformation of $n$-Decane on PtHY Catalysts. Journal of Cataylsis. 1996. 162(2): 179-189

Campelo J M, Lafont F, Marinas J M. Hydroconversion of n-dodecane over Pt/SAPO-11 catalyst. Applied Catalysis A: General. 1998. 170(1): 139-144

Coasne B, Grosman A, Ortega C and Simon M. Adsorption in noninterconnected pores open at one or at both ends: A reconsideration of the origin of the hysteresis Phenomenon. Physical Review Letters. 2002. 88: 256102-256105

Emies C A. Determination of integrated molar extinction coefficients for infrared absorption bands of pyridine adsorbed on solid acid catalysts. Journal of Catalysis. 1993. 141(2): 347-354

Francesconi M S, López Z E, Dayana U D, et al. MFI/MEL intergrowth and its effect on $n$-decane cracking. Catalysis Today. 2005. 107108(30): 809-815

Geng C H, Zhang F, Gao Z X, et al. Hydroisomerization of n-tetradecane over Pt/SAPO-11 catalyst. Catalysis Today. 2004. 93-95(1): 485-491

Girgis M J and Tsao Y P. Impact of catalyst metal-acid balance in $n$-hexadecane hydroisomerization and hydrocracking. Industrial and Engineering Chemistry Research. 1996. 35(2): 386-396

Gopal S and Smirniotis P G. Factors affecting isomer yield for n-heptane hydroisomerization over as-synthesized and dealuminated zeolite catalysts loaded with platinum. Journal of Catalysis. 2004 225: 278287

Gregg S J and Sing K S W. Adsorption, surface area and porosity (2nd Edition). London: Academic Press. 1982

Hu Y F, Wang X S, Guo X W, et al. Effects of channel structure and acidity of molecular sieves in hydroisomerization of $n$-octane over bifunctional catalysts. Catalysis Letters. 2005. 100(1-2): 59-65

Höchtl M, Jentys A and Vinek H. Acidity of SAPO and CoAPO molecular sieves and their activity in the hydroisomerization of $n$-heptane. Microporous and Mesoporous Materials. 1999. 31: 271285

Kerby M C, Degnan Jr T F, Marler D O and Beck J S. Advanced catalyst technology and applications for high quality fuels and lubricants. Catalysis Today. 2005. 104(1): 55-63

Kokotailo G T, Schlenker J L, Dwyer F G and Valyocsik E W. The framework topology of ZSM-22: A high silica zeolite. Zeolites. 1985. 5(6): 349-351

Kwang C P and Son K I. Comparison of Pt/zeolite catalysts for $n$-hexadecane hydroisomerization. Applied Catalysis A: General. 2000. 203(2): 201-209

Liu Y Q, Liu C Y, Liu C G, et al. Sn-modified Pt/SAPO-11 catalysts for selective hydroisomerization of $n$-paraffins. Energy \& Fuels. 2004. 18(5): 1266-1271

Marcilly C. Present status and future trends in catalysis for refining and petrochemicals. Journal Catalysis. 2003. 216(1-2): 47-62

Martens J A, Tielen M and Jacobs P A. Relation between paraffin isomerisation capability and pore architecture of large-pore bifunctional zeolites. Studies in Surface Science and Catalysis. 1989. 46: 49-60

Martens J A, Vanbutsele G, Jacobs P A, et al. Evidences for pore mouth and key-lock catalysis in hydroisomerization of long $n$-alkanes over 10-ring tubular pore bifunctional zeolites. Catalysis Today. 2001. 65(2-4): 111-116

Mazurek M, Benker N, Roth C and Fuess H. Binary mixtures of carbon supported Pt and Ru catalysts for PEM Fuel Cells. Fuel Cells. 2006. 
(6): 208-213

Miller, S. J. Catalytic isomerization process using a silicoaluminophosphate molecular sieve containing an occluded group VIII metal therein. US Patent. 4689138. 1987

Miller S J and Rosenbaum J M. Method for producing a plurality of lubricant base oils from paraffinic feedstock. US Patent. 6962651. 2005

Mills G A, Heinemann H, Milliken T H and Oblad A G. (Houdriforming Reactions) Catalytic Mechanism. Industrial and Engineering Chemistry. 1953. 45: 134-137

Murphy W J, Soled S L, Cody I A, et al. Lube basestocks manufacturing process using improved hydrodewaxing catalysts. US patent. USP7662273. 2010

Nieminen V, Kumar N, Heikkilä T, et al. Isomerization of 1-butene over SAPO-11 catalysts synthesized by varying synthesis time and silica sources. Applied Catalysis A: General. 2004. 259(2): 227-234

Niu X L, Song Y Q, Xie S J, Liu S L, et al. Synthesis and catalytic reactivity of MCM-22/ZSM-35 composites for olefin aromatization. Catalysis Letters. 2005. 103(3-4): 211-218

Park K C and Ihm S K. Comparison of Pt/zeolite catalysts for n-hexadecane hydroisomerization. Applied Catalysis A: General. 2000. 203(2): 201-209

Ramos M J, Gómez J P, Dorado F, et al. Hydroisomerization of a refinery naphtha stream over platinum zeolite-based catalysts. Chemical Engineering. 2007. 126(1): 13-21

Rohrman Jr A C, LaPierre R B, Schlenker J L, et al. The framework topology of ZSM-23: A high silica zeolite. Zeolites. 1985. 5(6): 352354

Rollmann L D, Schlenker J L, Lawton S L, et al. On the role of small amines in zeolite synthesis. Journal of Physical Chemistry B. 1999. 103(34): 7175-7183

Saberi M A, Van Mao R L, Martin M, et al. Effect of Zn loading of the Pt-Zn-HY trifuncitional catalysts on the hydroisomerization of n-hetane. Appllied Catalysis A. 2001. 214(2): 229-236

Thybaut J W, Narasimhan C S L, Denayer J F, et al. Acid-metal balance of a hydrocracking catalyst: Ideal versus nonideal behavior. Industrial and Engineering Chemistry Research. 2005. 44(14): 51595169

Walendziewski J and Pniak B. Synthesis, physicochemical properties and hydroisomerization activity of SAPO-11 based catalysts. Applied Catalysis A: General. 2003. 250(1): 39-47

Wang B C, Tian Z J, Li P, et al. Synthesis of ZSM-23/ZSM-22 intergrowth zeolite with a novel dualtemplate strategy. Materials Research Bulletin. 2009. 44: 2258-2261

Weitkamp J. Isomerization of long-chain $n$-alkanes on a $\mathrm{Pt} / \mathrm{CaY}$ zeolite catalyst. Industrial \& Engineering Chemistry Product Research and Development. 1982. 21(1): 550-558

Wittenbrink R J, Bauman R F and Ryan D F. Biodegradable high performance hydrocarbon base oils. US Patent. 6506297. 2003

Woltz C, Jentys A and Lercher J A. Improving bifunctional zeolite catalysts for alkane hydroisomerization via gas phase sulfation. Journal of Catalysis. 2006. 237(2): 337-348

Yang X M, Ma H J, Xu Z S, et al. Hydroisomerization of n-dodecane over Pt/MeAPO-11( $\mathrm{Me}=\mathrm{Mg}, \mathrm{Mn}$, Co or $\mathrm{Zn})$ catalysts. Catalysis Communications. 2007. 8(8): 1232-1238

Zones S, Burton J and Allen W. Zeolite SSZ-54 composition of matter and synthesis thereof. US Patent. USP6676923. 2004

(Edited by Zhu Xiuqin) 